Przegląd Badań Edukacyjnych

ISSN 1895-4308

nr 18 (1/2014), s. 249-258

DONIESIENIA

Z PRAKTYK

EDUKACYJNE

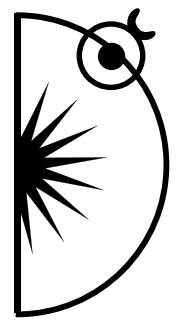

Dorota Kowalczyk

\title{
Koncepcja i praktyka edukacji nauczycieli w Uniwersytecie Jagiellońskim wobec nowych standardów
}

DOI: http://dx.doi.org/10.12775/PBE.2014.017

\section{Wprowadzenie}

Jakość kwalifikacji zawodowych nauczyciela staje się wyznacznikiem organizacji oświaty we wszystkich europejskich systemach oświaty publicznej. Wykształcenie takiego nauczyciela, który ma poczucie własnego profesjonalizmu, czuje się ekspertem w swojej dziedzinie oraz świadomie i odpowiedzialnie korzysta ze swego czołowego miejsca $\mathrm{w}$ procesach edukacyjnych, wiąże się ze wskazaniem tych dyspozycji i sprawności, które pomogą mu w twórczym i odważnym wypełnianiu funkcji zawodowej. Wśród tych dyspozycji można wskazać, obok rzetelnej wiedzy zawodowej, krytycyzm i głęboki namysł nad faktami, zjawiskami i procesami, których jest świadkiem, w których uczestniczy oraz które sam inicjuje i organizuje.

Koncepcja nauczyciela w programie Studium Pedagogicznego Uniwersytetu Jagiellońskiego jest próbą urzeczywistnienia w praktyce edukacyjnej elementów współczesnych dyskursów nad jakością uniwersyteckiej edukacji nauczycieli. Współczesna rola szkoły została przeformułowana - ma być przewodnikiem po świecie wolności i oferentem postaw. Ład demokratyczny wymaga od ludzi kompetencji poznawczych, krytycznych, interpretacyjnych, 
decyzyjnych, opanowywania umiejętności znajdowania się w sytuacji ambiwalencji przezwyciężania stresów, tworzenia sensownych relacji między tym, co osobiste, a tym, co ogólne, między różnicującymi się interesami, akceptowania i radzenia sobie ze stanem płynnej równowagi, uczenia się odpowiedzialności i kierowania własnym życiem. Praktyczna realizacja modelu kształcenia kandydatów na nauczycieli spośród studentów Uniwersytetu Jagiellońskiego jest próbą odpowiedzi na pytania o zmianę w edukacji, jest próbą redefinicji sytuacji, w jakiej spotykają się nauczyciel i uczeń.

Celem spotkania i wspólnej pracy wykładowców i studentów w Studium Pedagogicznym jest przygotowanie do wykonywania zawodu nauczyciela w taki sposób, by podejmujący pracę absolwent, $\mathrm{z}$ jednej strony reprezentował wysokie kompetencje profesjonalne (będące uzupełnieniem wiedzy zdobytej w macierzystym instytucie), i z drugiej, świadomie realizował pewien etyczny standard wychowawcy. Podstawowe zadania nauczyciela ogniskują się wokół pracy z uczniem, jednak celem działania nauczyciela jest nie tyle przyswojenie przez ucznia określonych treści, co optymalizacja jego rozwoju, stwarzanie warunków dla rozwoju osobowości, indywidualnego, aktywnego otwarcia na sferę wartości, wreszcie prowadzenie do nabycia sprawności życiowych, w tym nawyku zdobywania wiedzy i samorozwoju . Zatem od poziomu przygotowania, kompetencji osobowościowych i motywacji do działania samych nauczycieli zależeć będzie jakość edukacji. Transformacja świadomości społeczeństwa, zmiany mentalne, zwłaszcza nauczycieli wymagają daleko idących przeobrażeń systemu edukacji nauczycieli.

\section{Koncepcje edukacji nauczycieli}

Koncepcja edukacji nauczycieli zaproponowana w Studium Pedagogicznym Uniwersytetu Jagiellońskiego ma u swych podstaw metodologicznych założenia konstruktywizmu oraz koncepcji refleksyjnej praktyki.

Wobec niepowtarzalności sytuacji w klasie kandydat musi być zdolny do zachowania swoistej mobilizacji do stałego analizowania i rozumienia sytuacji edukacyjnej. $Z$ punktu widzenia pragmatyki pedagogicznej rozumienie owej sytuacji sprowadza się do twórczej racjonalizacji opisu opartej na doświadczeniach, wiedzy, umiejętnościach, ale także na pewnym konkretnym systemie wartości. W konsekwencji - zdaniem K. Pacławskiej - możliwe jest formułowanie celów działania, optymalizacja doboru metod, postrzeganie otoczenia i siebie samych jako aktywnych, dynamicznych warunków, nie tylko ograniczających, ale i otwierających oryginalne możliwości rozwiązania, szcze- 
gólnie problemów typowych w sytuacjach edukacyjnych: w perspektywie dziecka - ucznia, szkoły, środowiska rodzinno-wychowawczego i całego społeczeństwa.

Zajęcia edukacyjne w Studium Pedagogicznym UJ mają dostarczyć kandydatowi do zawodu nauczyciela szerokiego spojrzenia na proces edukacyjny, jednocześnie $\mathrm{z}$ bardzo mocno zaakcentowaną swoją rolą w przebieg tego procesu, we własny rozwój profesjonalny.

Podstawą zajęć jest refleksja i komunikowanie się studentów między sobą oraz aktywizowanie i analiza posiadanej przez nich wiedzy (tej związanej z nauczaniem, ale i z domem rodzinnym oraz systemem wartości). Kandydat musi być zainteresowany własnym uczeniem się z przejęciem pełnej odpowiedzialności za ten proces (autonomiczna decyzja o zdobywaniu kwalifikacji nauczycielskich i przyjęcie warunków uczenia się zaproponowanych w programie i organizacji Studium).

Inne ujęcie relacji teorii i praktyki, odkrycie jej interaktywnego charakteru, potwierdzenie nauczycielskiej wiedzy praktycznej spowodowało, że nauczyciele akademiccy w swej pracy ze studentami nie mogą już dłużej się ograniczać do przekazywania wiedzy formalnej. Główne zadanie edukacji nauczycielskiej upatruje się we wspomaganiu rozwoju osobistej wiedzy nauczycielskiej i to w relacji do praktyki. Okazało się też, że czynić to można skutecznie tylko we współpracy z nauczycielami szkół ćwiczeń, w których przyszli adepci profesji nauczycielskiej spędzają czasami połowę czasu przeznaczonego na kształcenie. Zmiana poglądu na rolę teorii, odejście od traktowanie jej jako bazy dla wyprowadzania wydajnych systemów nie oznacza jednak deprecjonowania jej wartości. Wprost przeciwnie, wiedzy formalnej przypisuje się fundamentalne znaczenie jako bazie refleksji uruchamianej przez praktykę .

Profesjonalna edukacja nauczycieli składa się najczęściej z trzech elementów:

$-\mathrm{z}$ teorii edukacji,

- studiów profesjonalnych,

- praktyki szkolnej .

W pierwszym z wymienionych obszarów znajdujemy głównie treści dotyczące historii edukacji, psychologii rozwoju, filozofii edukacji, dydaktyki ogólnej i socjologii edukacji. Czasami ujęte są one w postaci samodzielnych przedmiotów akademickich, częściej jednak teorie reprezentujące wyżej wskazane dziedziny wiedzy ujęte są integralnie; nie wprowadza się studenta $\mathrm{w}$ język, metodologię, strukturę dyscypliny, lecz wykorzystuje się tylko te elementy, które są użyteczne dla nauczania i czyni się to zawsze z praktycznymi doświad- 
czeniami. W Studium Pedagogicznym odpowiadają takiej wizji odpowiednie treści z zakresu pedagogiki ogólnej i psychologii ogólnej.

Studia profesjonalne zagospodarowują tę część programu, która przeznaczona jest na kształcenie praktycznych nauczycielskich umiejętności (to proponowane m.in. w Studium Pedagogicznym zajęcia warsztatowe). Stąd główną metodą pracy w tym zakresie jest metoda warsztatowa, polegająca na wychodzeniu od osobistych doświadczeń studentów (każdy z nich posiada ogromny potencjał przeżyć związanych z faktem bycia edukowanym, edukującym czy osobą postronną względem pewnych procesów edukacyjnych), aktywności, osobistym kontakcie (nauczyciele i studenci są sobą, nie zasłaniają się rolą), emocjach, uczeniu wzajemnym i uruchamianiu samooceny. Omawiana metoda pozwala więc w pełni wykorzystać to, co student wnosi ze sobą do procesu edukacyjnego - jego wiedzę, wartości, emocje, to co może odkryć dzięki własnej aktywności, oraz to, co może wynieść dzięki współpracy z innymi.

Przykładowe implikacje zastosowania koncepcji refleksyjnej praktyki w edukacji nauczycieli w Studium Pedagogicznym można ująć następująco:

- najbardziej „wartościowe” uczenie się to uczenie się poprzez eksperymentowanie;

- zasadniczą część programu stanowi studiowanie praktyki, a więc rzeczywistych, problematycznych, kompleksowych i otwartych na różnorodność interpretacji sytuacji;

- pedagogika wspiera profesjonalne uczenie się poprzez organizowanie warunków i sposobności do rozwijania zdolności fundamentalnych dla kompetentnej praktyki, takich np. jak: empatii, samorefleksji odnośnie własnych sądów i działań, „oglądania” sytuacji z różnych punktów widzenia;

- nabywanie wiedzy jest procesem interaktywnie związanym z prowadzeniem refleksji nad rzeczywistymi sytuacjami etc.

Wśród znacznego zróżnicowania zadań kursowych dość często wymagane są od kandydatów na nauczycieli prace pisemne, realizowane jako analizy zagadnień na bazie literatury i własnych doświadczeń piszących, jako analizy i recenzje specjalistycznych tekstów, jako krytyczne osądy materiałów publicystycznych, jako opisy wykonywanych prac terenowych w placówkach edukacyjnych, jako badanie dokumentów psychologicznych, pedagogicznych, jako projekty badań diagnostycznych dotyczących np. umiejętności uczniów i inne.

Interakcja między wiedzą akademicką i praktyczną wydaje się kluczowym punktem nowych europejskich programów kształcenia nauczycieli. Uniwersytety stają wobec nowego wyzwania - rozwijania podstawowych badań dla 
nowych koncepcji edukacji nauczycielskiej. Istnieje też potrzeba skoncentrowania się nad określeniem wymagań w stosunku do edukatorów przyszłych nauczycieli, jak i tworzenia oraz umacniania pozycji programów edukacyjnych tychże „nauczycieli nauczycieli”. Osiągnięcie tego stanu rzeczy stanowiłoby wartościowy wkład do procesu profesjonalizacji czynności nauczycielskich.

\section{Praktyka edukacji nauczycieli}

Celem działalności Studium jest kształcenie studentów Uniwersytetu Jagiellońskiego zainteresowanych uzyskaniem kwalifikacji pedagogicznych do pracy nauczycielskiej, które są niezbędne do zatrudnienia na stanowisku nauczyciela we wszystkich szkołach i placówkach oświatowo-wychowawczych.

Decyzja o podjęciu kursu w Studium Pedagogicznym UJ jest kwestią indywidualnego, świadomego wyboru. „Nauczyciel” jest antycypacją jednej z ról, jaką student przyjmuje jako element swojego profesjonalnego wyboru . Zgłoszenie się do Studium traktuje się jako deklarację woli spełnienia wymagań stawianych przez dyrekcję Studium w zakresie dyscypliny w trakcie odbywania kursu i co najmniej minimum zaangażowania w realizację wspólnego celu. Niezbędna w nowych czasach przebudowa systemu edukacji uniwersyteckiej otworzyła pole dla większej samodzielności studentów. W Studium Pedagogicznym mogą więc indywidualnie decydować, kiedy realizować kurs w Studium, w jakich dniach i godzinach uczęszczać na zajęcia. Dyplom/Zaświadczenie ukończenia Studium Pedagogicznego studenci otrzymują po zakończeniu studiów kierunkowych. Stwarza to możliwość przyjęcia przez studenta innego programu działań w myśl własnych założeń, z przejęciem pełnej odpowiedzialności za podjętą decyzję. W kulturze indywidualizmu zdaniem H. Kędzierskiej i M. Maciejewskiej przyjmuje się, że jakość pracy szkoły jest determinowana przez jakość pracy nauczyciela. Nauczycielom stawia się wymagania i dokonuje oceny ich pracy z perspektywy stopnia ich wypełniania zgodnego z przyjętymi standardami. Dlatego istota przygotowania kandydata w Studium tkwi w psychopedagogicznym kształceniu do wykonywania roli nauczyciela. Program kursu obejmuje zakres wiedzy i umiejętności z zakresu psychologii i pedagogiki, zgodnie z rozporządzeniem Ministerstwa Nauki i Szkolnictwa Wyższego z 17 stycznia 2012 r. w sprawie standardów kształcenia przygotowującego do wykonywania zawodu nauczyciela. Zajęcia z dydaktyk przedmiotowych w instytutach macierzystych, a także przeprowadzane pod nadzorem ich pracowników praktyki w szkołach są integralną częścią curriculum Studium Pedagogicznego i wchodzą w zakres obowiązku w ramach kursu przygotowa- 
nia pedagogicznego. Absolwent studiów I stopnia uzyskuje przygotowanie do nauczania w szkolnictwie podstawowym, natomiast absolwent studiów II stopnia do nauczania w szkolnictwie ponadpodstawowym. Obok poziomu ukończonych studiów niezbędne do nauczania na danym poziomie szkolnictwa jest również zrealizowanie $\mathrm{w}$ trakcie przygotowania pedagogicznego zajęć przygotowujących do pracy na danym etapie szkolnej edukacji.

W ofercie Studium Pedagogicznego znajdują się także zajęcia warsztatowe oraz zajęcia z emisji głosu, które pozwalają studentom na precyzowanie i rozwijanie zainteresowań problematyką edukacyjną oraz nabywanie konkretnych umiejętności pedagogicznych. W procesie stawania się nauczycielem świadomy wybór zajęć warsztatowych oraz aktywne w nich uczestniczenie jest podstawą do nabywania umiejętności racjonalnego i twórczego spojrzenia na edukację. W proponowanych słuchaczom Studium Pedagogicznego tytułach zajęć podkreśla się wartość i znaczenie rozwijania kompetencji interpretacyjnych oraz komunikacyjnych, nie zaniedbując kompetencji technicznych umożliwiających twórcze i efektywne budowanie sytuacji edukacyjnej. W rozważaniach nad zawodem nauczyciela kandydat zostaje zaproszony do refleksji profesjonalnej, kim jest, kim powinien być nauczyciel, jaka jest droga jego rozwoju, w jaki sposób dąży do mistrzostwa. Konieczne jest zatem bardzo szerokie spojrzenie na zawód nauczyciela oraz jego profesjonalne kompetencje. Być współczesnym nauczycielem to przede wszystkim posiadać silną motywację do wykonywania tego zawodu; znać i rozumieć cele edukacyjne, a także umieć myśleć i interpretować otaczający świat.

Zgodnie ze standardami kandydaci do zawodu nauczyciela uzyskuja w Studium Pedagogicznym UJ :

1. Ogólne przygotowanie psychologiczno-pedagogiczne:

- psychologia - 45 godz.,

- pedagogika - 45 godz.

Przygotowanie psychologiczno-pedagogiczne do nauczania na danym szkolnym etapie edukacyjnym lub etapach edukacyjnych:

2. dla szkoły podstawowej:

a) psychologia - 30 godz.

b) pedagogika - 30 godz.

3. dla szkolnictwa ponadpodstawowego:

a) psychologia - 30 godz.,

b) pedagogika - 30 godz.

4. Praktyka ogólnopedagogiczna - 30 godz.

5. Podstawy dydaktyki -30 godz. 
Kandydaci do zawodu nauczyciela realizują zajęcia edukacyjne z dydaktyk przedmiotowych oraz realizują praktyki pedagogiczne w macierzystych instytutach:

1. Dydaktyka przedmiotowa na danym szkolnym etapie edukacyjnym lub etapach edukacyjnych:

- dla szkoły podstawowej - 90 godz.

- dla szkolnictwa ponadpodstawowego - 90 godz.

2. Praktyka - 120 godz. (odpowiednio dla każdego etapu).

3. Ewentualnie dydaktyka II przedmiotu (dla odpowiedniego etapu edukacyjnego - 60 godz.) i praktyka dydaktyczna (60 godz.).

Tabela 1. Realizacja zajęć edukacyjnych pozwalających uzyskać kwalifikacje do pracy nauczycielskiej na studiach I i II stopnia

\begin{tabular}{|l|c|c|c|}
\hline \multicolumn{4}{|c|}{ Studia I stopnia } \\
\hline Pedagogika ogólna & 45 godz. & I semestr & 3 punkty ECTS \\
\hline Psychologia ogólna & 45 godz. & I semestr & 3 punkty ECTS \\
\hline Pedagogika dla SzP & 30 godz. & II semestr & 2 punkty ECTS \\
\hline Psychologia dla SzP & 30 godz. & II semestr & 2 punkty ECTS \\
\hline \multicolumn{3}{|c|}{ Studia II stopnia } \\
\hline Pedagogika dla szk. Ponadpodstawowego & 30 godz. & II semestr & 2 punkty ECTS \\
\hline Psychologia dla szk. Ponadpodstawowego & 30 godz. & II semestr & 2 punkty ECTS \\
\hline \multicolumn{3}{|c|}{ Studia I lub II stopnia } \\
\hline Podstawy dydaktyki & 30 godz. & I lub II semestr & 2 punkty ECTS \\
\hline
\end{tabular}

Źródło: opracowanie własne

Tabela 2. Realizacja zajęć edukacyjnych pozwalających uzyskać kwalifikacje do pracy nauczycielskiej na studiach II stopnia (dla wszystkich etapów edukacyjnych)

\begin{tabular}{|c|c|c|c|}
\hline \multicolumn{4}{|c|}{ Studia II stopnia } \\
\hline Pedagogika ogólna & 45 godz. & I semestr & 3 punkty ECTS \\
\hline Psychologia ogólna & 45 godz. & I semestr & 3 punkty ECTS \\
\hline Pedagogika dla SzP & 30 godz. & II semestr & 2 punkty ECTS \\
\hline Psychologia dla SzP & 30 godz. & II semestr & 2 punkty ECTS \\
\hline Podstawy dydaktyki & 30 godz. & I lub II semestr & 2 punkty ECTS \\
\hline Pedagogika dla szk. ponadpodstawowego & 30 godz. & III semestr & 2 punkty ECTS \\
\hline Psychologia dla szk. ponadpodstawowego & 30 godz. & III semestr & 2 punkty ECTS \\
\hline
\end{tabular}

Źródło: opracowanie własne 
Blok przygotowania psychologiczno-pedagogicznego do jednego etapu szkolnej edukacji ma wartość 10 punktów, a do obydwu 14.

Egzaminy i zaliczenia kończące kurs przygotowania do zawodu nauczyciela w Studium Pedagogicznym UJ mają wskazać na osiągnięcia w rozwoju zawodowym kandydata na nauczyciela w zakresie kompetencji praktyczno-moralnych, w tym interpretacyjnych, komunikacyjnych i moralnych, rozumienia sytuacji edukacyjnej, czyli twórczej racjonalizacji opisu opartej na doświadczeniach, wiedzy, umiejętnościach, a także na pewnym konkretnym systemie wartości, oraz kompetencji technicznych, a więc umiejętności zastosowania konkretnych, wypracowanych projektów i metod działania w sytuacjach edukacyjnych zgodnie z ogólnym i szczegółowym opisem efektów kształcenia zawartych w Standardach kształcenia przygotowującego do wykonywania zawodu nauczyciela. Zaliczenia i wyniki egzaminów zajęć prowadzonych w SPUJ dokumentowane są wpisami w systemie USOS.

Oferta Studium dla słuchaczy kursu zawodowego zawiera zajęcia obligatoryjne realizowane $\mathrm{w}$ formie konwersatoriów i fakultatywne (warsztatowe). Zakres obowiązku uczestniczenia w zajęciach określony jest $\mathrm{w}$ opisie poszczególnych kursów.

Absolwent Studium Pedagogicznego UJ w swojej pracy nauczycielskiej ma wyznaczać i utrzymywać wysokie standardy nauczania; współdziałać z różnorodnymi grupami uczniów, których potrzeby, motywacje, biografie oraz zdolności są odmienne od nauczyciela; reagować na nowe wyzwania; być zaangażowanym, pełnym entuzjazmu i wiary w siebie, mimo problemów życia klasowego i szkolnego.

\section{Bbibliografia}

Czerepaniak-Walczak M. (2000), Badanie $w$ działaniu-jego rola $w$ rozwoju profesjonalizmu nauczyciela $i$ w reformowaniu edukacji, [w:]: Kształcenie pedagogiczne w dobie przemian edukacyjnych $w$ Polsce, red. K. Wenta, Materiały Konferencyjne nr 46, Szczecin.

Dylak S. (2000), Konstruktywizm jako obiecujaca perspektywa w ksztatceniu nauczycieli, [w:] Współczesność a kształcenie nauczycieli, red. H. Kwiatkowska, T. Lewowicki, S. Dylak,. WSP ZNP, Warszawa.

Dylak S. (2010), Ksztattowanie (sie) pedagogicznej wiedzy nauczycielskiej - w procesie stawania się nauczycielem - epitafium, [w:] Metodologiczne problemy tworzenia wiedzy w pedagogice. Oblicza akademickiej praktyki, red. J. Piekarski, K. Szmidt, D. Urabaniak-Zając, Wydawnictwo Impuls. 
Fish D., Brockman H. (1992), Odmienne podejście do kształcenia nauczycieli, „Forum Oświatowe" nr 7.

Gołębniak B.D. (1995), Między akademickim przekazem a studiowaniem praktyki, „Studia Edukacyjne" nr 1.

Gołębniak B.D. (1998), Zmiany edukacji nauczycieli. Wiedza - biegłość - refleksyjność, Wydawnictwo „Edytor”, Toruń-Poznań.

Gołębniak B.D. (2010), Poszukiwanie, dziejowość, dialektyczne uczenie się. Nowe praktyki edukacyjne w szkole wyższej, [w:] Zmiana kształcenia w szkole wyższej, red. J. Piekarski i D. Urbaniak-Zając, Wydawnictwo UŁ, Łódź.

Kwaśnica R. (2003), Wprowadzenie do myślenia o nauczycielu, [w:] Pedagogika: podręcznik akademicki, t. 2, red. B. Śliwerski, Z. Kwieciński, Warszawa.

Kwiatkowska H. (2011), Standardy ksztatcenia nauczycieli. Opinia o projekcie rozporzadzenia Ministra Nauki i Szkolnictwa z dnia 24 maja 2011 roku, „Rocznik Pedagogiczny”, vol. 34 .

Kwieciński Z. (1998), Zmienić kształcenie nauczycieli, [w:] Edukacja nauczycielska w perspektywie wymagań zmieniajacego się świata red. S. Siemak-Tylikowska. Warszawa.

Pacławska K. (1997), Model nauczyciela w ksztatceniu uniwersyteckim. Kompetencja do zmiany i rozwoju. Koncepcja nauczyciela w programie Studium Pedagogicznego Uniwersytetu Jagiellońskiego, [w:] Źródta inspiracji współczesnej edukacji nauczycielskiej, red. H. Kwiatkowska, T. Lewowicki. Warszawa.

Pacławska K. (1998), Studium Pedagogiczne UJ (1921-1996). Edukacja dla niepodległości i rozwoju, [w:] Tradycja i Wyzwania. Edukacja, Niepodległość, Rozwój, red. K. Pacławska, Wydawnictwo „Universitas”, Kraków.

Schön D. (1987), Educating the Reflective Practitioner, Jossey Bass: London.

\section{The concept and practice of teacher education at the Jagiellonian University with respect to new standards}

\section{Summary}

The article attempts to describe the state of teacher education at the Jagiellonian University after the introduction of the new standards of preparation for teaching. The concept of teacher education proposed in the College of Education at the Jagiellonian University is based on methodological assumptions of constructivism and the concept of reflective practice and the purpose of meeting and collaboration of faculty and students is to prepare for the teaching profession in such a way that agraduate undertaking work, on the one hand, represents high 
professional competence, (to complement the knowledge gained in the home institute) and on the other, consciously pursues a certain ethical standard of an educator. The decision to take the course in the College of Education at the Jagiellonian University is the issue of individual, informed choice. Therefore, at the College of Education, students can individually decide when to pursue a course, on which days and hours to attend classes. The essence of the candidate's preparation at the College lies in psycho-pedagogical education to perform the role of the teacher. The course covers the knowledge and skills in terms of psychology and pedagogy, in accordance with Regulation of the Minister of Science and Higher Education of 17.01.2012 on the standards of education in preparation for the teaching profession. Classes on subject didactics in parent institutes, and internships carried out in schools under the supervision of their employees are an integral part of the curriculum of the College of Education and fall within the scope of the duty in the course of pedagogical preparation training. Students receive the certificate of graduation from the College of Education after graduation from applicable studies. This creates the possibility of adopting a different program of action by the student in accordance with their own assumptions, taking full responsibility for the decisions taken.

Keywords: new standards of preparation for teaching, concept of teacher education, practice of teacher education, Jagiellonian University. 